\title{
BRAF Inhibitor
}

National Cancer Institute

\section{Source}

National Cancer Institute. BRAF Inhibitor. NCI Thesaurus. Code C155322.

Any agent that inhibits the serine/threonine-protein kinase BRAF(B-RAF). 